\title{
Biblical Studies and Bible Translations in Hungary in the Age of the Reformation 1540 $-1640$
}

\section{Holy Writ - Sacred Writing}

\subsection{Theology}

The Reformation - in Europe and Hungary alike - had determined itself by the Bible from the start. "My conscience is captive to the Word of God," said Luther in 1521, during the Imperial Diet in Worms. ${ }^{1}$ Paradoxical as it may sound, this self-definition significantly transformed the Bible itself. When looking back on the "century of Reformation"2 from the twenty-first century, we tend to view this change as the process of reading, interpretation, and evaluation of the written text (the "Scripture"). If, however, we look at the different steps of knowing and absorbing the Bible in a historical context, it is easy to see that this motion went in the opposite direction. The one-time users of the Bible - from the publication of the first Protestant Hungarian translation of the Bible to the printing of the first Catholic Hungarian Bible - reached the text itself from the absolute self-value of Holy Writ, through the axioms of interpretation believed to be eternal, independent of textual facts.

When Protestant movements are discussed, we often hear that the Reformation made the Bible the foundation of faith. This is only true if the word "faith" denotes belief. If, however, we use the word "faith" as a means of gaining salvation, the order is reversed: faith is the basis of biblical criticism and not the other way around - in other words, the principle of sola fide (by faith alone) precedes the principle of sola scriptura (by Scripture alone). This is brilliantly demonstrated by a painting from the parish of a Lutheran congregation in Györköny (in Tolna County). ${ }^{3}$ The painting depicts Luther and Frederick the Wise around the ark of the covenant, resting on the rock of "faith;" the Holy Bible is placed on the ark, topped by a menorah (a candlea-

1 Roland H. Bainton, Here I stand: A Life of Martin Luther (Nashville: Hendrickson, 1980 [1950]), 185; Larry D. Mansch, and Curtic Peters, Martin Luther: The Life and Lessons (Jefferson, NC: McFarland \& Co., 2016), 119.

2 Pál Ács and Howard Louthan, "Bibles and Books: Bohemia and Hungary," in A Companion to the Reformation in Central Europe, eds. Howard Louthan, and Graeme Murdock (Leiden/Boston: Brill, 2015), 402.

3 J. Heltai and B. Gáborjáni Szabó, eds., Biblia Sacra Hungarica. "A könyv, mely örök életet ád” [“The Book that Gives Eternal Life"], exhibition catalogue, Hungarian National Széchényi Library, November 21, 2008 - March 29, 2009 (Budapest, 2008), 158. 


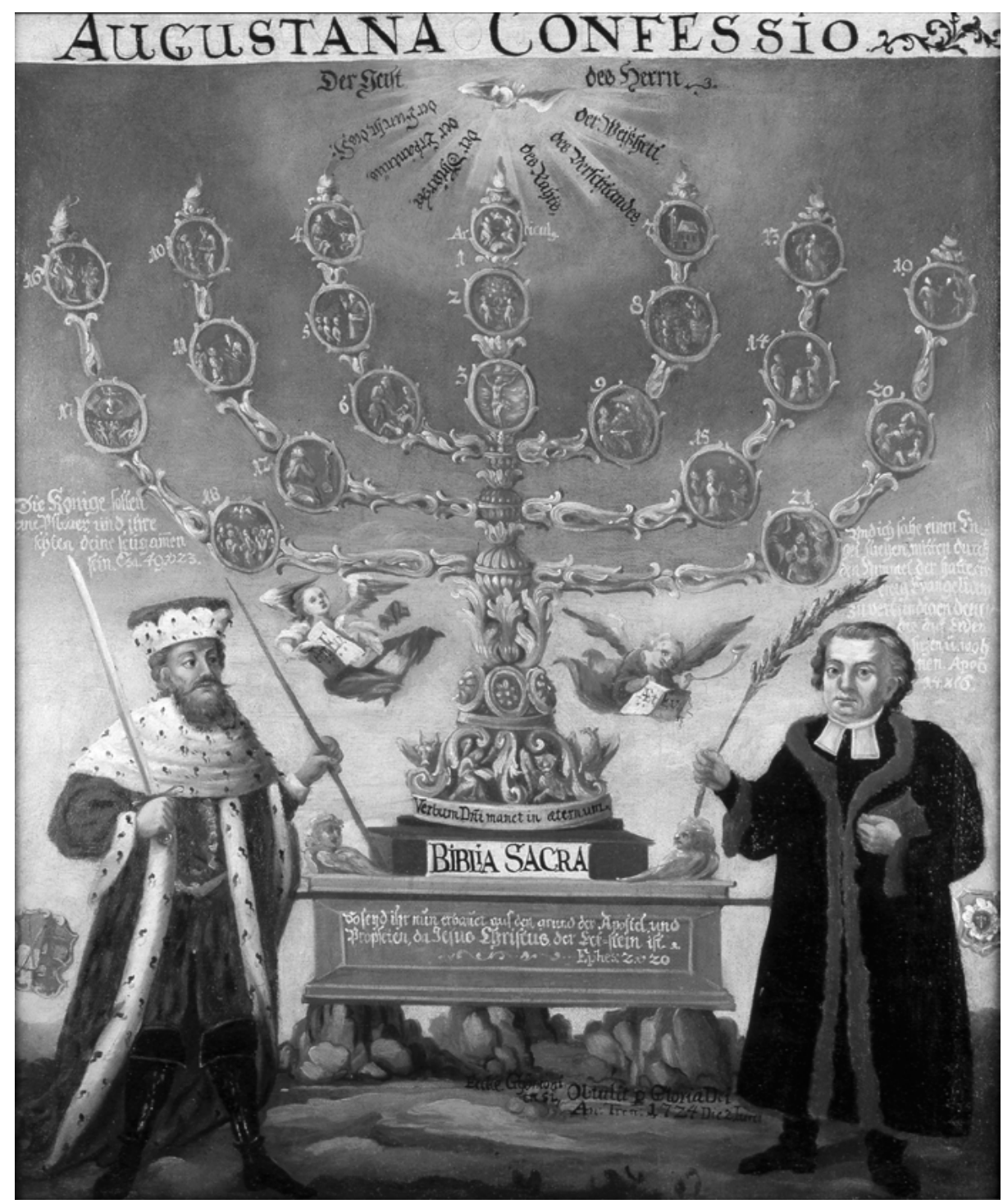

Fig. 1 Allegory of Augustana Confessio with Frederick the Wise and Luther. Unknown master, terminus ante quem: 1724 . Canvas, oil. $95 \times 78 \mathrm{~cm}$. It is the property of the Evangelical-Lutheran Parish of Györköny, Tolna County, Hungary. Deposit in the Lutheran Museum, Budapest. It is a copy of an 1630 etching by Jacob van der Heyden (1573-1645). Photo: Lutheran Museum, Budapest

bra with seven branches) symbolizing the Augsburg Confession, the "branches of faith."

Most Bible users (regardless of religion) of the time interpreted Holy Scripture thus illuminated by faith as the word of God. The fact that the Bible had been dictated word for word was later placed in the 1675 text of Formula Consensus Helvetica, 
extending divine inspiration beyond consonants of the Hebrew text of the Old Testament to vowel signs (the Masoretic Hebrew punctuation), as well. ${ }^{4}$ As István Gyulai, a Transylvanian Protestant translator of the Bible, said in 1551, "this kowledge did not come from man or an angel, but from the almighty and wise God himself." The preface to György Káldi's Jesuit translation of the Bible says that the Holy Spirit is "the creator of Holy Scripture" (1626). ${ }^{6}$ The Protestant Gáspár Károlyi explains in his dedication to the Vizsoly Bible (1590) that until the appearance of Moses, God talked to the fathers "through his own sacred mouth." Later he revealed himself to Moses and the prophets, and finally "through his Son."7 Thus, God first talks, then he himself writes on Moses' stone tablets, while his "words" are written down later by the prophets and evangelists, inspired by the Holy Spirit.

Everybody familiar with the Bible knew that the expression "the word of God" (translated thus from the Greek logos) did not simply denote a book. The famous prologue to John's Gospel (according to most interpretations) calls the word the eternal "person" (hypostasis) of the one and indivisible God. ${ }^{8}$ The word is thus God's Son on one hand, and God's creating word on the other ("through whom all things came into existence"), but also the concrete verbal revelation of God - directly inspired by the Holy Spirit (who, according to the famous filioque addition to the Constantinopolitan Creed in $381,{ }^{9}$ proceeds from the Father "and the Son") - to the prophets and evangelists, who are thus simple spokesmen, scribes of the words of God. The created world and the Bible are both "books" of God, the expressions of his word, and this is emphasized by almost all Hungarian translators of the Bible. György Káldi cites Saint Paulinus of Nola (353/54-431) as a remarkable example, as he used to have two niches (tabernacles) in his church - one for the Eucharist, and one for the Holy Scripture. ${ }^{10}$ With this gesture, Saint Paulinus emphasized the double (mystical and concrete) presence of the word in the life of the congregation.

So when Luther - and, in his traces, Hungarian Reformers - claimed to be "captive to the word of God," he (and they) may have meant at least three things: the "Word" - the Son of God, Christ, as they were his followers; the "word" - that is, Holy Scripture, as they considered it to be God's own sacred writing, his written mes-

\footnotetext{
4 Jorge L. Borges, “A Defense of the Kabbalah,” in Selected Non-Fictions, ed. Eliot Weinberger (New York: Penguin, 2000), 83.

5 G. Heltai et al., trans., Biblia [The Holy Bible], 7 vols. (Kolozsvár, 1551-1565); E. Zvara, ed., 'Az keresztyén olvasóknak'. Magyar nyelvü bibliafordítások és -kiadások előszavai és ajánlásai a 16-17. századból ["To the Christian Readers." Forewords and Dedications of $16^{\text {th }}-17^{\text {th }}$ Century Hungarian Bible Translations and Editions] (Budapest, 2003), 72.

6 Heltai et al., Biblia, 212.

7 Heltai et al., Biblia, 175.

8 Rudolf Bultmann, Theology of the New Testament, trans. Kendrick Grobel (Waco, TX: Baylor University Press, 1951), 2:21-25.

9 A. Edward Siecienski, The Filioque: History of a Doctrinal Controversy (Oxford: Oxford University Press, 2010).

10 Zvara, 'Az keresztyén olvasóknak', 211.
} 
sage; and the "word" that the Holy Spirit dictates to his prophets as direct inspiration, as they considered themselves to be the heirs of the prophets, the hearers of the word. This is characteristically summarized in András Farkas' poem, "On the Jewish and Hungarian Nations" (1538), one of the earliest and most significant works of the literature of the Hungarian Reformation:

\author{
God has sent us \\ Many wise people and candid teachers \\ Who preach us through the Word \\ The salvation of the Blessed Jesus Christ... ${ }^{11}$
}

The first Hungarian Reformers - especially Mátyás Dévai, the so-called "Hungarian Luther"12 - promoted the institution of a universal priesthood in Hungary, as well. ${ }^{13}$ Few then suspected the dangers of this spirituality that emphasized direct inspiration.

\title{
1.2 Hermeneutics
}

In the beginning, the early Reformation inarguably followed medieval heretical movements in the interpretation of the Bible. ${ }^{14}$ When Mátyás Dévai - imprisoned for his Protestant views in Vienna in 1533 - wanted to make preaching available to everyone, including women, he touched on an extremely sensitive issue. ${ }^{15}$ Christianity had long argued about who is entitled to explain the Bible. In the Middle Ages, the Catholic Church made a clear distinction between the narrative and moralizing parts of Holy Scripture (aperta) and the dogmatically important texts (profunda). ${ }^{16}$ The former, easily understandable episodes did not fall under any ban; however, only clerics were entitled to explain and interpret the latter (and to have the Eucharist with bread and wine). Heretics wanted to take these privileges away from priests. The book and the chalice were the most characteristic symbols of the contents of

11 B. Varjas, ed., Balassi Bálint és a 16. század költöi [Bálint Balassi and the Poets of the $16^{\text {th }}$ Century] (Budapest, 1979), 1:393.

12 Jan-Andrea Bernhard, Konsolidierung des reformierten Bekenntnisses im Reich der Stephanskrone. Ein Beitrag zur Kommunikationsgeschichte zwischen Ungarn und der Schweiz in der frühen Neuzeit (1500-1700) (Göttingen: Vandenhoeck \& Ruprecht, 2015), 188-206.

13 Z. Csepregi, A reformáció nyelve. Tanulmányok a magyarországi reformáció első negyedszázadának vizsgálata alapján [The Language of the Reformation: Studies about the Reformation in the Hungarian Kingdom during the First Quarter of the Sixteenth Century] (Budapest, 2013), 228-38.

14 Alan J. Hauser, and Duane F. Watson, A History of Biblical Interpretation, vol. 2, The Medieval through the Reformation Periods (Grand Rapids, MI/Cambridge: Eerdmans, 2009).

15 Csepregi, A reformáció nyelve, 229-30.

16 Jacques Le Goff, Saint Francis of Assisi (London/New York: Psychlogy Press, 2004), 10. 
their movements. ${ }^{17}$ They translated the Bible into their own languages everywhere in Europe to provide an advantage to their preachers in the free interpretation of God's word. The Protestant translations of the Bible offered the word "freely," without requiring a human mediator - not so much for reading as for preaching -, just as the Protestant communion omitted the gesture of "transubstantiation," denying the notion that it is the words of the ordained priest that (by God's power) make the bread and wine into the Lord's body and blood.

The Anabaptist revolutions throughout Europe, turning radically interpreted Scripture into bloody deeds, ${ }^{18}$ soon intimidated Reformers away from the "institution" of a universal priesthood - promoted by Mátyás Dévai - and the free, spiritual explanation of the Bible. Hungary was only lightly brushed by these storms, ${ }^{19}$ but this was enough to make Hungarian Protestants more cautious. The Reformation experienced a tough situation: on the one hand, it could not give up the freedom of biblical interpretation; on the other hand, it had to define limits against unlimited interpretation. The dedication to the Vizsoly Bible summarizes several decades of cautious Protestant hermeneutics: "We should not boldly accept every piece of information coming from somebody's mouth; instead, we should compare it with the writings of the prophets and the apostles, as the Holy Spirit instructs us.” The meaning is clear: the Bible cannot be interpreted by angels, devils, or diets, as Holy Scripture explains itself. This means that it is ultimately Christ who illuminates Holy Scripture, because - as Gáspár Károlyi cites the Gospel of John - "no one has ever seen God but the Son." 20

In practice, this meant that the dogmatically important parts (profunda) of the Old Testament were viewed in the mirror of the New Testament. István Gyulai, a member of the Bible translation workshop of Gáspár Heltai, clearly explains that the first words of the book of Genesis must be interpreted as a testimony to the Holy Trinity: "Because the one who created the world is the Father. And the Word he spoke is the Son of God, as Saint John says. And the soul of God floating on water and giving it life is the Holy Spirit of God proceeding from the Father and the Son." ${ }^{21}$ Thus, when Protestant hermeneutics explained several Old Testament texts - the book of Psalms, the Song of Songs, the book of Jonah, the book of Daniel, the book of Ezekiel, the book of Revelation, and many other biblical texts - figuratively, as announcements referring to the future, it applied the method of Jewish bib-

17 Thomas A. Fudge, Jan Hus. Religious Reform and Social Revolution in Bohemia (London/New York: I.B. Taurus, 2010); N. Nowakowska, "Reform before Reform? Religios Currents in Central Europe, c. 1500," in A Companion to the Reformation, 121-43; Ph. Haberken, "The Lands of the Bohemian Crown. Conflict, Coexistence, and the Quest for the True Church," in A Companion to the Reformation, 11-39.

18 Alastair Hamilton, The Family of Love (Cambridge: James Clarke \& Co., 1981), 14-17.

19 Csepregi, A reformáció nyelve, 187-93.

20 John 1:18; see also Zvara, ‘Az keresztyén olvasóknak”' 176.

21 Zvara, 'Az keresztyén olvasóknak,' 81. 
lical interpretation, the pesher 22 ("solution") type, popular in the ancient Christian Church (the commentary on the Apocalypse was one of the most popular genres in this age, which was so sensitive to apocalypticism). ${ }^{23}$ This Jewish interpretation technique, also used by the authors of the New Testament, developed into both post-biblical Jewish and Christian biblical hermeneutics - that is, the four layers of meaning of Holy Scripture, built on each other: literal (that is, historical), moral, allegorical, and anagogic (referring to the future) layers of meaning. The scholastic explanation of the Bible was also based on this four-storey theory. ${ }^{24}$ We know that Dante applied the same procedure in the aesthetics of literature, ${ }^{25}$ from which Coluccio Salutati placed it back into theology, emphasizing that God is the greatest poet $^{26}$ and that the Bible was not historia but fabula, ${ }^{27}$ as its more profound meaning is elaborated in allegories, just like in poetry.

Nevertheless, Bible translations made in the framework of the Reformation opposed all those who "seek spiritual meaning in all of the Old Testament." ${ }^{28}$ Thus, Protestants tried to tame unlimited allegorizing and "origenizing” - named after the creator of this method, Origen, who had lived in second- and third-century Alexandria - that insisted on the four layers of meaning. ${ }^{29}$ According to Luther and his Hungarian followers, allegories are "overdecorated whores," ${ }^{30}$ and only the literal interpretation (sensus historicus) of the Bible is acceptable. With this spectacular gesture - so it may seem -, they simultaneously excluded scholasticism and literature from their field of vision. While Erasmus had praised the richness of words (copia verborum), Luther declared it useless (inutilis verborum copia). ${ }^{31}$

22 Geza Vermes, The Changing Faces of Jesus (London: Penguin, 2000).

23 C. L. Beckwith, ed., Refomation Commentary on Scripture. Old Testament 12. Ezekiel, Daniel (Downers Grove, IL: InterVarsity Press, 2012); S. Bene, "Ratio temporum. Dániel próféta és a magyar történetírás" [The Prophet Daniel and Hungarian Historiography], in Clio inter arma. Tanulmányok a 16-18. századi magyarországi történetírásról [Studies on $16^{\text {th }}-18^{\text {th }}$ Century Hungarian Historiography], ed. G. Tóth (Budapest, 2014), 87-116; Sándor Őze, Apocalypticism in Early Reformation Hungary (Budapest/Leipzig: Leipzig University Press, 2015).

24 P. Ács, “'Én fiam vagy, Dávid...' A historikus értelmezés korlátai a 2. zsoltár unitárius fordításában" ["You Are My Son, David..." Limits of Historical Interpretation in the Unitarian Translation of Psalm 2], Irodalomtörténeti Közlemények 111 (2008): 632-44.

25 Charles S. Singleton, Allegoria, in La poesia della Divina Commedia (Bologna: Il Mulino, 1990), 17 $-35$.

26 Paul R. Blum, Philosophy of Religion in the Renaissance (Farnham: Ashgate, 2010), 65.

27 Peter G. Bietenholz, Historia and Fabula. Myths and Legends in Historical Thought from Antiquity to the Modern Age (Leiden: Brill, 1994).

28 Zvara, 'Az keresztyén olvasóknak,' 83.

29 Henning G. Reventlow, History of Biblical Interpretation, vol. 3, Renaissance, Reformation, Humanism (Atlanta: SBL, 2010).

30 WA.TR 1:607,6 (Nr. 1219).

31 Clarence H. Miller, ed., Erasmus and Luther. The Battle over Free Will, trans. Clarence H. Miller and Peter Macardle (Indianapolis, IN: Hackett, 2012), 83. 
We have good reason to ask how it is possible that Protestant Bibles continued to allegorize, relating several passages of the Old Testament to the New Testament (interpreting them as "prefigurations"). The answer is that they attributed a literal meaning to the figurative planes of meaning (the prophecies that may relate to Christ) relevant to them, not considering these as allegories at all. Thus, the Reformation simply regulated the typological thinking that assumed a strong link between the Old and New Testaments instead of supressing it altogether. The great Protestant hermeneutical change occurred at the second level of the explanation of the Scripture: mystical interpretation was replaced by prophetic interpretation. ${ }^{32}$ As we can see, nobody in the age of the Reformation argued the fact that the Bible is a text with two meanings - a literal and a spiritual layer. "That is why our Lord Christ tells the Jews to get acquainted with the Scripture (the Old Testament), because it proves him” - writes István Gyulai. ${ }^{33}$

\subsection{Philology}

Gáspár Heltai's Bible translation circle was aware that "even the Turks say that the book called Alcoran is the knowledge of God [...] They also say that [...] their books were brought from God by the angel Gabriel." ${ }^{34}$ This is a clear allusion to the Muslim belief that God's announcements have a heavenly core copy - an original matrix, the mother of the "book" (Umm-ul-Kitab) - from which the earthly copies are made. ${ }^{35}$ Christian concepts of the text of the Bible were very similar. Some Lutheran theologians refrained from listing Scripture among created things, as they interpreted it as the embodiment of the Holy Spirit. ${ }^{36}$ Needless to say, different religions held different views on the authentic earthly copy of the "heavenly original." Orthodox Christians, with reference to the miracle of the Translation of the Seventy, believed in the perfection of the Greek Septuagint, ${ }^{37}$ while Western Christianity respected - in György Káldi's words - "the old one in Latin, called Vulgata Editio," referring to "the great treasure" of the Holy Spirit "given to the Church," thanks to which Saint Jerome's translation faithfully kept the "real meaning" of Holy Scripture. ${ }^{38}$ We know - as Gáspár Károlyi, a translator of the Bible, also suggests - that the dogmatically

32 Ács, “Én fiam vagy, Dávid,” 638.

33 Zvara, 'Az keresztyén olvasóknak,' 83.

34 Zvara, 'Az keresztyén olvasóknak,' 77.

35 R. Simon, A Korán világa [The World of the Quran] (Budapest, 1987), 79; J. D. McAuliffe, ed., The Cambridge Companion to the Quran (Cambridge: Cambridge University Press, 2006), 3; Borges, "A Defense of the Kabbalah," 83.

36 Zvara, 'Az keresztyén olvasóknak,' 77.

37 N. Fernández Marcos, The Septuagint in Context. Introduction to the Greek Version of the Bible (Leiden: Brill, 2000).

38 Zvara, 'Az keresztyén olvasóknak,' 214. 
respected Bible is a version of the Latin Bible annotated by the ninth-century Carolingian scholar Alcuin and standardized in Paris in the thirteenth century. ${ }^{39}$

Humanist Bible experts insisted on the previously neglected Greek studies and challenged the authority attributed to the Vulgate. Lorenzo Valla studied the Greek manuscripts of the New Testament extensively and corrected the text of the Vulgate several times; ${ }^{40}$ later, Erasmus of Rotterdam also retranslated it from Greek (1516), and Hungarian Erasmian Bible translators ${ }^{41}$ based their work on this highly important edition. ${ }^{42}$ The works of Pico della Mirandola and Johannes Reuchlin provided important inspiration for Christian Hebraism, and as a result, the Old Testament was read, studied, and translated in and from Hebrew. ${ }^{43}$ The first polylingual Bible, Biblia Polyglotta Complutensia (1514-1517), was published in Alcala ${ }^{44}$ - it was widely used in Hungary, too -, while the institution for studying the three sacred languages, Collegium Trilingue (1517) was founded in Leuven, inspired by Erasmus. ${ }^{45}$

The Bible translation program of the Hungarian Reformation also returned to the ancient sources of sacred texts and followed Erasmus' principle - to provide the Holy Writ to "each nation in its own language." 46 However, in many respects, they did not like the Erasmian Hungarian translations of the first half of the sixteenth century. ${ }^{47}$ Gáspár Heltai and his circle - the translators of the first, almost complete Hungarian Bible - insisted on Luther's view, adjusting their translation principles to it and considering Luther's 1522-1534 German language Bible translation as authoritative. The Wittenberg reformer shared his principles on Bible translation in his Table Talk: "in case of ambiguity [...] I considered the meaning [...] that is more in harmony with the New Testament." ${ }^{28}$ He made it clear: Christ interprets Scripture as far as theology and hermeneutics - and also grammar and philology - are concerned. "Because the Holy Spirit does not always follow grammar [...] grammar must, however, follow the mean-

39 A. Hamilton, "Humanists and the Bible," in The Cambridge Companion to Renaissance Humanism, ed. J. Kraye (Cambridge: Cambridge University Press, 1998), 102.

40 J. Monfasani, "Criticism of Biblical Humanists in Quattrocento Italy," in Biblical Humanism and Scholasticism in the Age of Erasmus, ed. Erika Rummel (Leiden: Brill, 2008), 15-38.

41 Heltai and Gáborjáni Szabó, Biblia Sacra Hungarica, 148-57.

42 Hamilton, Humanists and the Bible, 111-12.

43 Allison Coudert and Jeffrey S. Shoulson, eds., Hebraica Veritas? Christian Hebraists and the Study of Judaism in Early Modern Europe (Philadelphia: University of Pennsylvania Press, 2004).

44 Erika Rummel, Jimenez de Cisneros. On the Threshold of Spain's Golden Age (Tempe, AZ: Arizona Center for Medieval and Reformation Studies, 1999), 53-65; Frances Luttikhuizen, Underground Protestantism in Sixteenth Century Spain: A Much Ignored Side of Spanish History (Göttingen: Vandenhoeck \& Ruprecht, 2017), 41-43.

45 Henry de Vocht, History of the Foundation and the Rise of the Collegium Trilingue Lovaniense, 1517 -1550, 4 vols, (Louvain: Kraus, 1951-1955).

46 Á. Ritoók-Szalay, "Erasmus und die ungarischen Intellektuellen des 16. Jahrhunderts," in Erasmus und Europa, ed. August Buck (Wiesbaden: Harrassowitz, 1988), 111-28.

47 Zvara, 'Az keresztyén olvasóknak,' 125

48 WA.TR 5:218,19f.. 
ing of the Holy Spirit," says István Gyulai, inspired by Luther. ${ }^{49}$ Thus, biblical studies still function as ancilla theologiae (the servant of theology). It would be a mistake to assume a significant theoretical difference between humanist and Protestant biblical studies. Humanist scholars of Greek, Christian Hebraists, and Protestants all agreed that the Bible has a heavenly matrix; they only differed in the methods they used to reconstruct this text. After all, everyone returned to the sources to reinforce his own principles of faith and to disprove those of his opponents. Cardinal Jiménez uses a very characteristic simile in his preface to the Alcala Bible. As we know, the text of the Latin Bible is surrounded by Hebrew and Greek texts in that edition. The cardinal compares the only true Latin Holy Scripture to the Savior crucified between the two thieves - that is, between the synagogue and Orthodox Christianity. ${ }^{50}$

It is useful to illustrate the mechanism of theology-led philology with the sixteenth- and seventeenth-century translations of one single word of one single "locus" of the Bible. The Church has always interpreted Psalm 22 as a prophecy of the crucifixion of Christ. In verse 17 (or 16, according to the Hebrew numbering), we read both in Gáspár Károlyi's Hungarian Bible ${ }^{51}$ and in the King James Version very similar interpretations: "For dogs have compassed me: the assembly of the wicked have enclosed me: they pierced my hands and my feet." The word "pierced" is the subject of a centuries-old controversy between Jewish and Christian interpreters of the Bible. The Hebrew Bible - in harmony with the text of the psalm - says: יראכ (kaari), that is, "like the lion." All Christian (Catholic and Protestant) Bibles in Europe and Hungary - from the Vulgate to the Septuagint and the different national translations - corrected this word, assuming that the true reading of the Hebrew text is וראכ (kaaru), that is, "cut through," and that Jewish copyists accidentally mixed up two very similar letters, wav and yod; thus, it is a simple distortion. Nobody on the Christian side took account of the fact that the word וראכ (kaaru) does not exist in Hebrew, and an aleph must also be deleted in order to create a Hebrew word meaning "pierced." The letters thus created, ורכ (karu), indeed mean "to dig" or "to cut through;" such a tradition, however, never existed in Hebrew manuscripts. This means that Christian philologists made a dogmatic decision on a philological question. The correction, however, could have been more than a simple conjecture. The translation of the Septuagint ( $\omega \rho) \xi \alpha v)$ shows that the minority interpretation with the meaning "pierced" is rather old and was already used in the time of Christ. ${ }^{52}$ This minority, Christian interpretation also seems to be supported by a papyrus frag-

49 Zvara, 'Az keresztyén olvasóknak,' 79.

50 Heltai and Gáborjáni Szabó, Biblia Sacra Hungarica, 188.

51 G. Károlyi, trans., Szent Biblia [The Holy Bible] (Vizsoly, 1590), 1:547r.

52 H.F.W. Gesenius, Hebrew and Chaldee Lexicon to the Old Testament Scriptures, ed. and trans. S. P. Tregelles (London, 1860), ccclxxxviii. 
ment from the first or second century, found near the Dead Sea. ${ }^{53}$ (Nevertheless, more arguments point to the correctness of the majority interpretation, "like the lion.") Every Hungarian Bible translator insisted on the "pierced" version - from the Evangelical Lutheran István Székely, ${ }^{54}$ translator of the Psalms, through the Reformed Gáspár Károlyi, to the Unitarian Miklós Bogáti Fazakas. ${ }^{55}$ This was true despite the fact that their sources had clearly mentioned the philological problems. Péter Melius, who was highly familiar with Hebrew, even wrote an essay on this and other similar issues to disprove "the blasphemy of rabbis." ${ }^{56}$ It is not surprising, then, that a translation faithful to the Masoretic Hebrew original - "like the lion" - is only found in the Psalm book (1624-1629) of Simon Péchi, a Szekler Sabbatarian who respected Jewish traditions. Péchi even remarks: "I had to stick to the sensus [literal meaning] because foderunt (pierced) does not exist in Jewish writings." 57

\section{The Hungarian Bible}

\subsection{Protestant Translations}

In the era discussed, several Hungarian Bible translations were made "in the framework of the Reformation." ${ }^{58}$ Each translation had a different method of creation and translation, a different theological concept, a different circle of supporters, and a different intention to create a canon. István Bencédi Székely's annotated translation of the Psalms (1548) was the first in this line. ${ }^{59}$ Székely’s work inarguably bore the sign of the Reformation, emphasizing that "in this work David speaks neither Jewish, Latin, nor Greek, but Hungarian.”60 Just like the Erasmian János Sylvester, ${ }^{61}$ Székely

53 P.W. Flint, "The Dead Sea Psalms Scrolls: Psalms Manuscripts, Editions, and the Oxford Hebrew Bible," in Jewish and Christian Approaches to the Psalms: Conflict and Convergence, ed. Susan Gillingham (Oxford: Oxford University Press, 2013), 11-34.

54 I. Székely, trans., Zsoltárkönyv [The Book of Psalms] (Krakow, 1548), 20r.

55 M. Bogáti Fazakas, trans., Magyar zsoltár [Hungarian Psalter], ed. G. Gilicze and G. Szentmártoni Szabó, epilogue R. Dán (Budapest, 1979), 49.

56 R. Dán, Humanizmus, reformáció, antitrinitarizmus és a héber nyelv Magyarországon [Humanism, Antitrinitarianism and Hebrew language in Hungary] (Budapest, 1973), 86; cf. Rowland G. Finch and George H. Box, eds., The Longer Commentary of R. David Kimhi on the first Book of Psalms (London: Society for Promoting Christian Knowledge, 1919), 102-03.

57 S. Péchi, trans., Psaltérium [The Book of Psalms], ed. Á. Szilády (Budapest, 1913), 36.

58 J. Horváth, A reformáció jegyében. A Mohács utáni félszázad irodalomtörténete [In the Spirit of the Reformation: The History of Hungarian Literature a Half Century after the Battle at Mohács] (Budapest, 1957).

59 Székely, Zsoltárkönyv.

60 Zvara, 'Az keresztyén olvasóknak,' 70.

61 The complete translation of the New Testament, published by János Sylvester in Sárvár-Újsziget (1541), closely follows the translation and commentaries by Erasmus. Sylvester remained a faithful 
was a "homo trilinguis": he knew the three sacred languages and translated from the Hebrew original instead of the text of the Vulgate. ${ }^{62}$ It is of course difficult to judge the extent of his knowledge of Hebrew, as his information came almost exclusively from Sebastian Münster's famous Hebrew-Latin Bible (Basel, 1534-1535). ${ }^{63}$ Münster, István Székely, and Christian Hebraists sought to reach a text in line with Christian faith on the basis of the principle of hebraica veritas (going all the way back to Saint Jerome) through the study of Hebrew sources. ${ }^{64}$ The antagonistic conflict between Christianity and the Jews was an axiom for them, too. ${ }^{65}$ Still, despite their Protestant conviction, they belonged to the humanist generation of the era preceding Protestantism in many respects. Not surprisingly, Luther often criticized Münster, who - according to Luther - was too close to the teachings of educated medieval rabbis (such as Rashi and David Kimhi). ${ }^{66}$ In the preface to his work, Székely promises to publish "the complete Bible soon." ${ }^{67} \mathrm{He}$ did not have time to do this, but his commentaries to the Psalms show that he had indeed planned to translate the book of Genesis.

One of the greatest - and, despite its merits, largely forgotten - achievements of Bible publication during the Reformation was the seven-volume work, published in Kolozsvár (today Cluj-Napoca, Romania) between 1551 and 1565, of the translation workshop led by Gáspár Heltai. ${ }^{68}$ It is evident that Heltai - who had a printing house, a paper mill, and a publishing workshop - used Gutenberg's invention to spread the Hungarian Reformation Bible, following European examples. ${ }^{69}$ The series contains almost the entire text of the Bible. The publication was funded by Prince Sigismund John and other Transylvanian aristocrats. ${ }^{70}$ However, this Holy Scripture was not only intended for distribution in Transylvania, but also in the Hungarian Kingdom - some examples did not contain a dedication to the prince. The volumes were held in high esteem by Lukács Ormosdi Székely, a Catholic aristocrat living in Western Transdanubia, very far from Transylvania. ${ }^{71}$ Calvinists also urged the com-

Catholic until the end of his life; he did not join the Reformation. See Ritoók-Szalay, Erasmus und die ungarischen Intellektuellen.

62 Dán, Humanizmus, reformáció, 47-60.

63 Heltai and Gáborjáni Szabó, eds., Biblia Sacra Hungarica, 178-79.

64 Erika Rummel, "Humanists, Jews, and Judaism," in Jews, Judaism, and the Reformation in Sixteenth-Century Germany, eds. Dean Bell, and Stephen G. Burnett (Leiden: Brill, 2006), 7-10.

65 See Shimon P. Markish, Erasmus and the Jews (Chicago: University of Chicago Press, 1986).

66 WA.TR 5:218.

67 Zvara, 'Az keresztyén olvasóknak,' 70.

68 Heltai, trans., Biblia.

69 Heltai and Gáborjáni Szabó, Biblia Sacra Hungarica, 166-69.

70 M. Balázs, "Heltai Gáspár zsoltárfordításáról” [On the Psalm Translations of Gáspár Heltai], in Biblia Hungarica Philologica. Magyarországi Bibliák a filológiai tudományokban [Bibles Printed in Hungary in Philological Studies], ed. J. Heltai (Budapest, 2009), 55.

71 F. Szakály, “A magyar nyelvü bibliafordítás terjedéséhez” [The Distribution of the Hungarian Bible Translation], in Müvelödési törekvések a korai újkorban. Tanulmányok Keserü Bálint tiszteletére [Cul- 
pletion of the Heltai Bible. In 1574, the bishop Péter Károlyi started to translate those books of the Old Testament that Gáspár Heltai and his group had not translated, but since Péter Károlyi died a year later, he could not finish the work. ${ }^{72}$

The members of Gáspár Heltai’s team were personal disciples of famous Bible researchers from Kraków and Wittenberg; the group had a few experts in Greek and Hebrew. One of the members of Heltai's group, Gergely Vízaknai, even published a Latin commentary on Genesis. The book of Sirach was translated into Hungarian in Tolna - in the territory of Ottoman Hungary - by Mátyás Tövisi and Imre Szigeti, with Heltai's group editing and correcting the text. ${ }^{73}$ With the books of the Old Testament, writes István Gyulai, “we followed the Jewish Bible, but we often distanced ourselves from the Jewish words, wishing to follow the Hungarian language for the sake of the true meaning."74 (These Horatian translation principles accompany the history of Hungarian Bible translations throughout.) Their whole translation method and theological perspective was in harmony with Luther's view and the Luther Bible. ${ }^{75}$ Heltai cuts a clear line between God's word and literary styles: "We should not consider these books or stories as fables or writings born from human feelings [...] they are not vain discussions or silly fables, but the true words of the blessed Lord," Heltai instructs. ${ }^{76}$ The book of Psalms - which Luther calls the "little Bible" - was translated into Hungarian by Gáspár Heltai himself. It is useful to compare it with István Székely's earlier work. No more humanist philology, no more insights, just Luther's clear message: "In this book, the Holy Spirit compares the two countries, the country of our Lord Jesus Christ and the country of the Saint King David."77 The whole series of books mediates Luther's evangelization to Hungarians: "let this world rage and feast. It will soon come to an end.”

In the meantime, the conditions of the Reformation were changing all over Hungary, divided into three periods. In the 1560s, Hungarian followers of the Swiss Reformation gained strength in many areas, while in the 1570s, especially in Transylvania and Ottoman Hungary, Antitrinitarians played an important role. It was in these rapidly changing times that the influential Calvinist minister of Debrecen, Péter Melius, translated the Bible. His most important funder was János Enyingi Török, a landholder of Debrecen. Melius also wanted to translate the entire Bible, but he only translated the two books of Samuel and Kings (Debrecen, 1565), the book of

tural Endeavours in the Early Modern Period. Studies in Honour of Bálint Keserú], ed. M. Balázs et al. (Szeged, 1997), 545-54.

72 See P. Károlyi, Az halálról, feltámadásról és az örök életről hasznos és szükséges könyvecske [Useful and Necessary Booklet on Death, Resurrection and Eternal Life] (Debrecen, 1574).

73 G. Kathona, Fejezetek a török hódoltságkori reformáció történetéből [Some Chapters of the History of the Reformation in Ottoman Hungary] (Budapest, 1974), 27-29.

74 Zvara, 'Az keresztyén olvasóknak,' 79.

75 Balázs, Heltai Gáspár zsoltárfordításáról, 79.

76 Zvara, 'Az keresztyén olvasóknak,' 131.

77 Zvara, 'Az keresztyén olvasóknak,' 121-22. 
Job (Debrecen, 1565), and the New Testament (1567); we do not have any copies of the latter. If we have a look at Melius' translations of the Bible, ${ }^{78}$ we immediately notice that the text is almost hidden among the commentaries in the margins: "I tell you what to know in the margin, next to the text," he says. Melius was an ardent reformer; he used the Bible as a powerful weapon in his struggle against Catholics, Antitrinitarians, and Anabaptists: "See, the Lord's grace comes to us each day, his country is built, and the devil's country is demolished. The light of the word of God shines brighter and brighter every day," teaches Melius. ${ }^{79}$ It is obvious that the most important thing for the Debrecen minister was no longer hermeneutics (in the sense of an introduction to the meaning of the Bible), but exegesis - that is, the transposition of hermeneutics into everyday life. Melius' comments in the margins are eminent sources on contemporary Hungarian circumstances. Melius studied exegesis extensively and made commentaries for almost the entire Bible; his translations were in line with his exegetical activities. He translated Hebrew texts into Hungarian from the editions, Latin translations, and commentaries of Münster, Vatablus (François Vatable), and Bible translators from Geneva. ${ }^{80}$ He liked to use - with Christian intentions, of course - the Kabbalah, the popular practice of post-biblical Jewish discipline. With the help of numerology, he decoded hidden meanings in Scripture - for instance, "the Pope is the Beast." Melius took part in the discussions of Swiss theologians on a high level. In one of his letters to Heinrich Bullinger, he sent him an essay (now lost) to disprove the grammatical arguments of highly respected Bible interpreters such as Joseph Albo, David Kimhi, and others - similarly to the textual considerations mentioned above in connection with Psalm 22. Thus, Péter Melius tried to lean on hebraica veritas, but, at the same time, he excluded from it the Jewish view of the Bible - following his Wittenberg master, Johannes Forster. Péter Melius often mentioned God as "Yahweh Elohim," even though he knew that the first Jewish name of God is singular, and the second one is plural. This is pure Melius exegesis, translated into Hungarian as "Holy Trinity One God."

Tamás Félegyházi’s translation of the New Testament was published in Debrecen in $1586 .^{82}$ The author, working closely with Péter Melius, had been a Reformed schoolmaster in Debrecen, but in 1570, he moved to the Antitrinitarian Kolozsvár, taking all his Debrecen students with him. ${ }^{83}$ In the next school year, however, Félegyházi returned to Melius and Debrecen. After Melius' death, he took his place as a minister. His New Testament with a Calvinist spirit was very popular in his time but has almost been forgotten by now. The book - similarly to those by Melius - provides

78 Heltai and Gáborjáni Szabó, Biblia Sacra Hungarica, 170.

79 Zvara, 'Az keresztyén olvasóknak,' 170.

80 J. P. Vásárhelyi, "Robert Estienne magyarországi hatása” [The Influence of Robert Estienne in Hungary], in Biblia Hungarica Philologica, 65-75.

81 Dán, Humanizmus, reformáció, 71-87.

82 Heltai and Gáborjáni Szabó, Biblia Sacra Hungarica, 172-73.

83 Horváth, A reformáció jegyében, 301. 
rich exegetical material in the margins, often taking up more space than the biblical text. Research has not yet concluded what sources Félegyházi used for his translation. Considering that the Hungarian Bible translator (a highly educated theologian) was deeply interested in the works of the Geneva reformer, Théodore de Bèze, it is highly probable that the source of the translation was Bèze's Latin New Testament, which was translated from Greek (first edition: Geneva, 1556), using the explanations attached to it. Bèze's New Testament was created with the specific aim of replacing Erasmus' translation, which was by then undesirable for the Geneva Reformation. ${ }^{84}$ Tamás Félegyházi died before finishing the work, and his colleague, György Gönci tried to fill in the gaps (he translated the Letter of Jude but did not write the commentaries to the book of Revelation) and also provided a preface.

The greatest Bible translation of the Hungarian Protestants, the Vizsoly Bible, edited by Gáspár Károlyi, dean of Gönc, ${ }^{85}$ was published four years later in Vizsoly in $1590 .{ }^{86}$ These ambitious plans were funded by wealthy Calvinist aristocrats from Eastern Hungary - András and Gáspár Mágócsy and Sigismund Rákóczi, the would-be Transylvanian prince. Rákóczi commissioned the printer Bálint Mantskovit to move all of his appliances from Galgóc (today Hlohovec in Slovakia) to Vizsoly and publish the Bible there. The Bible translation took about fifteen years, and it was printed over one and a half years (between February 1589 and July 1590). The great work was not done by a single author, but by a team of translators, similar to that of Gáspár Heltai, but Károlyi edited everything. ${ }^{87}$ They also used Heltai's edition - at least, the Old Testament part of the Károlyi Bible shows correspondences with Heltai's text. The Kolozsvár and Gönc translation teams used different methods; Heltai and his colleagues worked as a group, while Károlyi seemes to have distributed the work among his co-translators. Thanks to a fortunate discovery in the 1980s, researchers found a page of the print manuscript of the Vizsoly Bible with Károlyi's handwritten notes in the margin. ${ }^{88}$ The manuscript helped researchers reconstruct the different phases of editing and prepress. Gáspár Károlyi - whose preface to the Vizsoly Bible has been quoted above - worked against the Catholic view, which was dominant after the Council of Trent. He used an army of arguments to destabilize the authority of the Vulgate and announced a clear Protestant program of using and

84 B. Roussel, “Le Novum Testamentum de Théodore de Bèze. L'édition, la traduction, ez l'annotation de l'Épître de Jude,” in Theodore de Bèze, 1519-1605, ed. I.D. Backus (Genève, 2007), $185-94$. 85 A. Szabó, ed., Károlyi Gáspár a gönci prédikátor [Gáspár Károlyi, Minister of Gönc] (Budapest, 1984).

86 Heltai and Gáborjáni Szabó, Biblia Sacra Hungarica, 194-95.

87 A. Szabó, A rejtőzködő bibliaforditó: Károlyi Gáspár [The Hidden Bible Translator, Gáspár Károlyi] (Budapest, 2012).

88 A. Szabó, “A Vizsolyi Biblia nyomdai kéziratának töredéke” [A Fragment of the Print Manuscript of the Vizsoly Bible], Irodalomtörténeti Közlemények 87 (1983): 523-27. 
reading the Bible: ${ }^{89}$ "I shall never stop warning you that it is not enough to listen to what we say here; you must also read the Scripture at home."90 This theoretically significant program required centuries of development to be realized, as the Vizsoly Bible - which was of considerable size and weight - was far from being available to everyone. The translation group led by Károlyi enlarged the sources that had already been used previously in the modern translation of a Heidelberg professor of Hebrew, Immanuel Tremellius, "who was a Jew by nature." ${ }^{91}$ Research has recently shown that the 1 Samuel was translated on the basis of the translation and commentary of Petrus Martyr (Pietro Martire Vermigli). ${ }^{92}$ Gáspár Károlyi and his co-workers lead Hungarian readers toward an increasingly theologically crystallized, Protestant world of the Bible, but at the same time, they wished to stick to their traditions. The book of Esther, for instance, which shows great differences in Hebrew, Greek, and Latin sources, is begun according to the "true letter" - Hebrew - and continued according to the Septuagint and the Vulgate, while "some parts are not to be found anywhere," 93 as we read in the margin. Unfortunately, the quick printing in Vizsoly somewhat decreased the quality if the end result.

Albert Szenci Molnár corrected these mistakes - comparing the text with the best sources $^{94}$ - and redacted Gáspár Károlyi’s Bible according to an even more modern Calvinist standard (Hanau, 1608; Oppenheim, 1612). Szenci Molnár's editions separated deuterocanonical texts - or, to use the Protestant term, the biblical apocrypha from canonical ones and sought a more confined, more Puritan canonical order. At the same time, Szenci Molnár’s editions show that Gáspár Károlyi’s Bible was constantly developed and modified, following the current tendencies of Protestant Bible perspectives. The Károlyi Bible never really became the Holy Scripture of one denomination. Hungarian Lutherans also used it for a long time, as the idea of an independent Lutheran Bible only occurred in the eighteenth century. ${ }^{95}$

\subsection{Catholic Translations}

The Catholic Church has always refuted the widespread accusation of banning the reading of the Bible in national languages. It is indeed true that - according to me-

89 K. Péter, “Bibellesen. Ein Programm für jedermann im Ungarn des 16. Jahrhunderts," in Iter Germanicum. Deutschland und die Reformierte Kirche in Ungarn des 16-17. Jahrhundert, ed. A. Szabó (Budapest, 1999), 7-38.

90 Zvara, 'Az keresztyén olvasóknak,' 178.

91 Zvara, 'Az keresztyén olvasóknak,' 179; Heltai and Gáborjáni Szabó, Biblia Sacra Hungarica, 182 $-83$.

92 M. Imre, A Vizsolyi Biblia egyik forrása: Petrus Martyr [Peter Martyr, One of the Sources of the Vizsoly Bible] (Debrecen, 2006).

93 Károlyi, Szent Biblia, 1:507r.

94 Vásárhelyi, Robert Estienne, 70.

95 Z. Csepregi, Evangélikus bibliafordítások a 18. században, in Biblia Hungarica Philologica, 171-84. 
dieval practice - Catholic priests could use several Hungarian passages of the Bible. Miklós Telegdi's three-volume book of sermons ${ }^{96}$ featured his own translations of holy lessons (pericopes) for Sundays and festive days, based on the Vulgate (Vienna-Nagyszombat [today Trnava, Slovakia], 1577-1580). For a long time, this was the most complete Catholic extract of the Bible in Hungarian. The real turn came with the Jesuits, following the Council of Trent, which had fixed the status of the Bible. Seemingly, they simply wanted to preserve the authority of the Vulgate; in reality, they introduced a Catholic Reformation ${ }^{97}$ in response to the Protestant one, using the argumentative techniques of Protestants and turning them against their opponents. The famous Jesuit István Szántó Arator started to translate the Bible into Hungarian, but his manuscript is lost. ${ }^{98}$ Péter Pázmány, archbishop of Esztergom, a former Jesuit, mocked Protestant translations by saying "new translations are no more than insecure, unreliable, and contradictory pieces of grammarizing." 99 It is in this spirit that his fellow Jesuit, György Káldi, created the Hungarian Catholic Bible on the basis of the Vulgate, which would be used for centuries. Following a long permission procedure in Rome, it was published in Vienna in 1626. The handwritten fragments of the Káldi Bible were discovered recently in printing covers. ${ }^{100}$ In his Instructive Warning, cited above, Káldi also attacked Protestant translators, especially Gáspár Károlyi and Albert Szenci Molnár, because instead of translating God's pure and unambiguous words, they "keep selecting parts they like."101 He was extremely cunning in revealing that Protestant biblical scholars changed their beliefs too often. He tried to exploit the real interpretative conflicts of the Protestant side. We are still not fully aware of the history of Káldi's Bible. He could not have used Szántó Arator's lost work; he worked independently. It is possible, however, that he used a "two-hundred-year old," partial translation - very similar to the medieval Hungarian Bible translation of the Jordánszky Codex ${ }^{102}$ - that he referred to in his Instructive Warning. The Káldi Bible - as a Catholic fortress erected against Károlyi's Vizsoly Bible - made the division between Catholics and Protestants complete and final in the use of Holy Scripture as well.

96 Heltai and Gáborjáni Szabó, Biblia Sacra Hungarica, 202.

97 Michael A. Mullett, The Catholic Reformation (London: Psychology Press, 1999).

98 A. Molnár. "A horvát és magyar katolikus bibliafordítás és a római inkvizíciô" [The Croatian and Hungarian Catholic Bible Translations and the Roman Inquisition], Magyar Könyvszemle 119 (2002): 24-37.

99 P. Pázmány Hodogeus (Pozsony [today Bratislava, Slovakia], 1637); see E. Hargittay, "Pázmány Péter a Szentírásról és az Anyaszentegyházról” [Péter Pázmány on the Holy Scripture and the Mother Church], in 'Tenger az igaz hitrül való egyenetlenségek vitatásának eláradott özöne...' Tanulmányok 16-19. századi hitvitáinkról [Studies on $16^{\text {th }}-19^{\text {th }}$ Century Theological Disputes in Hungary], eds. J. Heltai and R. Tasi (Miskolc, 2005), 79-84.

100 P. Erdö, A Káldi-biblia kéziratos töredékei [Handwritten Fragments of the Káldi Bible], facsimile edition, (Budapest, 2015).

101 Zvara, 'Az keresztyén olvasóknak,' 247.

102 Heltai and Gáborjáni Szabó, Biblia Sacra Hungarica, 128-29. 


\section{The Bible and Literature}

\subsection{Psalmus Hungaricus}

In the century of the Reformation, Hungarian biblical literature was very rich. It would take a long time to enumerate biblical histories, jeremiads, verse commentaries, and biblical paraphrases. And if we intended to study the influence of the Bible on the literary language of the century, we would probably have to look at the entire literary corpus. However, paraphrases of the Bible cannot be considered Holy Scripture by any standard - contemporary or modern; they are simply parts of devotional literature, and we are not going to study them here. The Hungarian psalm literature in verse during the age of the Reformation is another issue, however. ${ }^{103}$ In the singing of psalms, of emphatic importance in the life of the Protestant communities, their spirituality and the world of the Bible were closely related. Members of the congregation sang psalms with the feeling that they were citing words of divine inspiration. The best Protestant poets of the sixteenth century - Mihály Sztárai, Gergely Szegedi, Máté Skaricza, and many others - all increased the number of psalms to be sung in congregations in Hungarian verse forms, to Hungarian melodies. By the end of the century, the Protestant psalms "of Hungarian verse forms" could almost fill an entire Psalter. ${ }^{104}$ However, these translations were severely criticized for taking too many liberties in mediating the words of the Bible. Imre Ujfalvi, the editor of a Protestant song book (Debrecen, 1602), remarked: "We should not remove or add anything when it comes to the text. Not to mention things that are alien to its spirit.” Protestants, according to increasingly Puritan principles, attacked the praefatios (introductory stanzas) and conclusions of psalms - as these, in their view, did not mediate God's words. They only tolerated psalms that followed the text of the Bible "without new meanings" and "without any kind of appendix."105

Albert Szenci Molnár's new Reformed translation of the Psalms (Herborn, 1607) was published with the explicit aim of including only "pure" songs, following the "true letter" in God's house. It is for this reason that Szenci Molnár translated the Geneva psalms, in perfect harmony with current Calvinist canonical principles, but which sounded strange to Hungarian ears - as they faithfully adhered to verse forms prescribed by French melodies. ${ }^{106}$ A year later, Szenci Molnár's book of psalms - which had great merits otherwise - became part of the revised Károlyi Bible and

103 É. Petrőczi and A. Szabó, eds., A zsoltár a régi magyar irodalomban [The Psalm in Ancient Hungarian Literature] (Budapest, 2011).

104 L. Bóta, “A magyar zsoltár Szenci Molnár Albert előtt” [Hungarian Psalms before Albert Szenci Molnár], in Szenci Molnár Albert és a késö-reneszánsz [Albert Szenci Molnár and the Late Renaissance], eds. S. Csanda and B. Keserü (Szeged, 1978), 163-78.

105 I. Újfalvi, Keresztyéni énekek [Christian Hymns] (Debrecen, 1602), facsimile edition and complementary study by P. Ács (Budapest, 2004), 20-21.

106 I. Bán, Szenci Molnár Albert, a költő [Albert Szenci Molnár, the Poet], in Szenci Molnár, 137-53. 
achieved a status (almost) equivalent to holy texts. The Geneva psalms did not entirely chase the traditional, and at the same time more permissive "Psalmus Hungaricus"107 from Calvinist churches; nevertheless, the free voice of the Holy Spirit became more and more silent. At the same time, Hungarian Unitarians (and Szekler Sabbatarians, who still belonged to the Unitarians at that time) - having different views than Calvinists on the sacredness of the text of the book of Psalms - created three complete Hungarian translations. Miklós Bogáti Fazakas ${ }^{108}$ and János Thordai ${ }^{109}$ developed the Hungarian Psalter in verse forms adapted to Hungarian melodies, with a significant amount of poetic freedom, while Simon Péchi ${ }^{110}$ used the results of postbiblical Jewish Bible discipline when translating psalms from Hebrew.

\subsection{Around the "Arian Bible"}

From the 1570s, deniers of the Holy Trinity became stronger than ever in Transylvania and in Ottoman Hungary, conducting heated debates on the dogmatically important parts of the Bible (profunda), making the worst dreams of the Catholic Church (and humanist criticism of the Bible) come true. ${ }^{111}$ The most abstract issues of the Holy Trinity were openly discussed everywhere, in pubs and in markets, ignoring (the otherwise highly respected) Erasmus' warning that theology is not for the uneducated. In Nagyharsány (in the territory of Ottoman Hungary) in 1574, those denying the Holy Trinity confronted their opponents in an open debate. György Alvinczi, an Antitrinitarian minister, said that the Bible "is like horse shit which contains grains of barley and oak, just as the Holy Scripture contains useful things." Since Alvinczi held the same opinion on the Quran, the Turkish qadi hung him. Shortly afterward, Antirinitarians confronted Calvinists in the Buda debate, reinforcing their view that the Bible - in the form then known - was a human creation with true and false aspects alike, so the best solution would be to print a Bible in which "human creations" are in small print, and divine creations are in capitals. ${ }^{112}$ It is not difficult to recognize here the views of famous heretic theologians who had fled to Transylvania. Jacobus Palaeologus, a Greek freethinker who had a fundamental influence on Hungarian

107 A traditional sixteenth-century translation of Psalm 55 by Mihály Kecskeméti Vég provided the basis for Zoltán Kodály’s famous choral work, Psalmus Hungaricus, composed in 1923.

108 Bogáti, Magyar zsoltár.

109 B. Stoll, M. Tarnócz, and I. Varga, eds., Az unitáriusok költészete [The Poetry of the Hungarian Unitarians]. (Budapest, 1967), 156-391.

110 Péchi, Psaltérium.

111 Ács, "Én fiam vagy, Dávid," 640.

112 M. Balázs, Teológia és irodalom. Az Erdélyen kívüli antitrinitarizmus kezdetei [Theology and Literature. The Beginning of Antitrinitarianism Outside Transylvania] (Budapest, 1996), 45-74. 
Unitarian thinking, ${ }^{113}$ had announced shortly before this, in a diet organized in Torda (today Turda in Transylvania), that he possessed a manuscript of the Gospel of John, written at a time near that of Jesus, which does not say "God was the Word" but "God's was the Word." According to Palaeologus, the original, correct text of the Gospel was intentionally distorted by Alexandrian theologians who believed in the Holy Trinity. We know from Jesuit sources that there was an intention to form a Bible translation workshop in Kolozsvár, led by Palaeologus, where the famous heretic Biblical scholars living in Transylvania - Johannes Sommer and Matthias Vehe-Glirius would have worked. ${ }^{114}$ The book would have been a new Latin translation of the Bible, replacing Santes Pagninus' Bible annotated by Michael Servetus (Lyon, 1542) $)^{115}$ and that of Sabastian Castellio, published in Basel in 1551. ${ }^{116}$ The theologians of the radical Reformation preferred these Bibles at the time. The "Arian Bible" of Kolozsvár could not have been made, and we do not know whether the Greek manuscript of the Bible (now lost) was really that old. It is also clear that Unitarian biblical criticism cannot be called academically objective in a modern sense, as Antirinitarians - just like their opponents who believed in the Holy Trinity - held dogmatic assumptions. ${ }^{117}$ The conclusion, however, is much more important: Palaeologus and his followers held completely different views on the authority of the Bible than anyone had before them. The work they planned wished to revise the Bible on the basis of common sense and sources considered dogmatically and textually authentic, and they did not attribute sacred significance to Scripture. As successors of Lorenzo Valla, Erasmus, and humanist studies of Holy Scripture, ${ }^{118}$ they believed that the philology of the Bible requires the same critical aspects as the literary works of profane authors. The Antitrinitarian criticism of the Bible took an important step towards not only treating Holy Scripture as a literary text, but considering most of it as such.

113 M. Rothkegel, "Iacobus Palaeologus und die Reformation. Antireformatische Polemik in der verlorenen Schrift Pro Serveto contra Calvinum," in Radikale Reformation. Die Unitarier in Siebenbürgen, eds. Ulrich A. Wien, Julia Brandt, András F. Balogh (Köln/Weimar/Wien: Böhlau, 2013), 91-134.

114 A. Pirnát, “A bibliakritika történetének egy ismeretlen fejezete” [An Unknown Chapter of Biblical Criticism], in Válogatott eretnekségek. Kiadatlan tanulmányok [Selected Heresies: Unpublished Studies], ed. P. Ács and M. Balázs (Budapest, 2017).

115 N. Fernández Marcos and E. Fernández Tejero, "Pagnino, Servet y Arias Montano. Avatares de una traducción latina de la Biblia Hebrea,” Sefarad 63 (2003): 283-329.

116 Carlos Gilly, Spanien und der Basler Buchdruck bis 1600. Einer Querschnitt durch die spanische Geistesgeschichte aus der Sicht einer europäischen Buchdruckerstadt (Basel/Frankfurt am Main: Verlag Helbing \& Lichtenhahn, 1985), 193; Ács, “Én fiam vagy, Dávid,” 638.

117 D. A. Frick, Polish Sacred Philology in the Reformation and the Counter-Reformation: Chapters in the History of Controversies 1551-1632 (Berkely: University of California Press, 1989), 81-115.

118 Albert Rabil, Jr., Erasmus and the New Testament: The Mind of a Christian Humanist (Lanham, MD: University Press of America, 1972); Hamilton, Humanists and the Bible; Monfasani, Criticism of Biblical Humanists. 


\subsection{Literary Criticism and Biblical Studies}

Other interpreters used other means in recognizing that the development of biblical studies was closely related to the growing richness of literature. János Rimay ${ }^{119}$ was the first to discuss general issues of the history of literature in his preface to Bálint Balassi's collected love poems. ${ }^{120}$ He started the preface with an ambitious summary of the history of culture. He designated the turn of the fourteenth to fifteenth centuries as the peak of great spiritual changes. By that time, he says, science and "handicrafts" - that is, techne arts - were developed enough to compete with "works of old times," the works of classical antiquity. A similar development took place in "written crafts": "we experience a wonderful gift of our Lord, decorating this era with the perfection of his word, with the true knowledge of his Holy Son, with the unambiguous revelation of his intentions." This statement by Rimay may only be interpreted to mean that humanism leads to the true knowledge of the Bible, which in turn leads to the Reformation. The true faith - the light of the "heavenly lamp" - drove away stupidity, and the Latin language was reinstated in its original nature, while "each national language" was strengthened, too. According to Rimay, the result and glorious completion of this renovation and the Reformation taking place in harmony with God's will was Bálint Balassi's love poetry, which many ignorant people criticized. It seems that in Rimay's eyes, humanism, the Renaissance, and the Reformation; the development of vernacular and Latin languages; biblical studies and fiction (bonae litterae) all formed part of the same unstoppable process. ${ }^{121}$ This process, however, did not move in the direction of "progress" in terms of breaking with the past, but rather the other way around: it was a "re-formatio" in the original sense of the word, ${ }^{122}$ the restoration of a former perfection. When János Rimay mentioned a deep link between the Renaissance and the Reformation, he carried on the spirit of Erasmus' biblical humanism. For Erasmus, the idea of converting the pagans meant that all of antiquity became sacred. ${ }^{123} \mathrm{He}$ was convinced that God had not only revealed himself to the Jews, but had planted the seed of the gospel in the soil of pagan centuries before the advent of Christ; thus, classic culture also hides the seeds of a more valuable Christian philosophy. This means that Christian humanism

119 János Rimay (1570-1631) was a distinguished Hungarian mannerist poet and a pupil of Bálint Balassi (1554-1594), the greatest Hungarian Renaissance poet. On Rimay, see P. Ács, "Ratio e oratio. Tipologie poetiche in János Rimay," Annali dell' Istituto Universitario Orientale di Napoli. Studi FinnoUngarici 1 (1995): 149-72.

120 J. Rimay, Összes müvei [Collected Works], ed. S. Eckhardt (Budapest, 1955), 39 -40.

121 Ács and Louthan, Bibles and Books, 404.

122 Z. Csepregi, "Die Auffassung der Reformation bei Honterus und seinen Zeitgenossen," in Radikale Reformation, 1-17.

123 P. Ács, "The Reception of Erasmianism in Hungary and the Contexts of the Erasmian Program: The 'Cultural Patriotism' of Benedek Komjáti," in "Whose Love of Which Country": Composite States, National Histories and Patriotic Discourses in Early Modern East Central Europe, eds. Balázs Trencsényi and Márton Zászkaliczky (Leiden: Brill, 2010), 75-90. 
- for Renaissance intellectuals - entailed not only the use of liberal arts in biblical studies, but a mutual sacredness in the service of universal salvation. 
